

\title{
pH and Eh effects on phosphorus fate in constructed wetland's sludge surface deposit
}

Boram Kim, Mathieu Gautier, Arnaud Simidoff, Corinne Sanglar, Vincent Chatain, Philippe Michel, Rémy Gourdon

\section{- To cite this version:}

Boram Kim, Mathieu Gautier, Arnaud Simidoff, Corinne Sanglar, Vincent Chatain, et al.. pH and Eh effects on phosphorus fate in constructed wetland's sludge surface deposit. Journal of Environmental Management, 2016, 183, part 1, pp.175-181. 10.1016/j.jenvman.2016.08.064 . hal-01372681

\section{HAL Id: hal-01372681 \\ https://hal.science/hal-01372681}

Submitted on 27 Sep 2016

HAL is a multi-disciplinary open access archive for the deposit and dissemination of scientific research documents, whether they are published or not. The documents may come from teaching and research institutions in France or abroad, or from public or private research centers.
L'archive ouverte pluridisciplinaire HAL, est destinée au dépôt et à la diffusion de documents scientifiques de niveau recherche, publiés ou non, émanant des établissements d'enseignement et de recherche français ou étrangers, des laboratoires publics ou privés. 


\title{
pH and Eh effects on phosphorus fate in
}

\section{constructed wetland's sludge surface deposit}

\author{
Boram Kim*, Mathieu Gautier*, Arnaud Simidoff, Corinne Sanglar, \\ Vincent Chatain, Philippe Michel and Rémy Gourdon
}

$\rightarrow$ To cite this version:

B. Kim, M. Gautier, A. Simidoff, C. Sanglar, V. Chatain, P. Michel and R. Gourdon. « $\mathrm{pH}$ and Eh effects on phosphorus fate in constructed wetland's sludge surface deposit ». Journal of environmental management, 2016, 183, pp 175181, DOI: 10.1016/j.jenvman.2016.08.064.

Please contact the corresponding author (*mathieu.gautier@insa-lyon ; boram.kim@insalyon.fr) if you are interested by a copy of the article published in the journal. 
pH and Eh effects on phosphorus fate in constructed wetland's sludge surface deposit

Boram Kim, ${ }^{\mathrm{a} b,},{ }^{*}$, Mathieu Gautier ${ }^{\mathrm{a},}$, Arnaud Simidoff ${ }^{\mathrm{a}}$, Corinne Sanglar ${ }^{\mathrm{c}}$, Vincent Chatain ${ }^{\mathrm{a}}$, Philippe Michel ${ }^{\mathrm{b}}$ and Rémy Gourdon ${ }^{\mathrm{a}}$

${ }^{a}$ Univ Lyon, INSA Lyon, DEEP, 20 av. A. Einstein, 69621 Villeurbanne cedex, France

${ }^{b}$ SCIRPE, Society of design and production engineering for wastewater purification, 5 Allée Alban Vistel, 69110 SainteFoyLèsLyon, France

${ }^{c}$ ISA, Institut des Sciences Analytiques, 5 rue de la Doua, 69100 Villeurbanne, France

* Corresponding authors.

E-mail address: mathieu.gautier@insa-lyon.fr

Address: DEEP

20 av. A. Einstein

F-69621 Villeurbanne Cedex

Tel.: +33(0)4 72438348

E-mail address: $\underline{\text { boram.kim@cpe.fr }}$

Address: Irstea, Wastewater treatment team

5 rue de la Doua

F-69626 Villeurbanne Cedex

Tel.: +33(0)4 72208780 


\begin{abstract}
The objective of the present study was to assess the influence of extreme $\mathrm{pH}$ and redox potential $(\mathrm{Eh})$ conditions on phosphorus $(\mathrm{P})$ retention within the surface sludge deposit layer of a vertical flow constructed wetland (VFCW) where phosphorus was captured by $\mathrm{FeCl}_{3}$ injection. Series of 27 successive batch leaching tests were conducted under acidic, alkaline or reductive conditions using a representative sludge sample taken from an 8-year old VFCW plant. Experiments were followed by monitoring the $\mathrm{pH}$ and Eh variations and analysing the releases of $\mathrm{P}$ and other selected elements into the solutions. The sludge material was also analysed before and after leaching, using solution ${ }^{31} \mathrm{P}$ NMR spectroscopy and sequential chemical extractions, in order to evaluate dissolutions of both organic and inorganic P-bearing species and their respective contributions to $\mathrm{P}$ release. The correlations between the monitored variables were analysed and visualized through principal components analyses (PCA). Results showed a very good stability of $\mathrm{P}$ retention in the sludge deposit and a relatively good acidbuffering capacity of the sludge, revealing that the risk of accidental $\mathrm{P}$ release into the environment would be extremely low during the real plant operation.
\end{abstract}

\title{
Keywords:
}

vertical flow constructed wetland; surface deposit; phosphorus leaching; environmental engineering; $\mathrm{pH}$; redox 


\section{Introduction}

Due to its role in eutrophication, its fertilizing value and the progressive depletion of its natural resources, phosphorus $(\mathrm{P})$ has become a key element to control in environmental policies worldwide (Cordell et al., 2009; Reijnders et al., 2014). Domestic wastewaters constitute significant $\mathrm{P}$ sources, originating mostly from human metabolism and detergents (respectively estimated around $1.2 \mathrm{~g}$ and $1 \mathrm{~g}$ of $\mathrm{P}$ per person and per day). Increasing research efforts have therefore been focused in the recent years on phosphorus recovery from domestic wastewaters (Brod et al., 2015a; 2015b; García-Albacete et al., 2012; Weigand et al., 2013) and sewage sludge (Kahiluoto et al., 2015; Peccia and Westerhoff, 2015; Wilfert et al., 2015). The development of chemical and biological treatments to enhance the fertilizing value of organic waste and/or sequester $\mathrm{P}$ in soil while maintaining its availability to crops has even been claimed as a major research need (Sharpley et al., 2015).

Constructed wetlands processes have proven well adapted to the treatment of various types of wastewaters (Vymazal and Kröpfelová, 2009). The efficiency of classical vertical-flow constructed wetland (VFCW) processes is very good in the treatment of carbon and ammonia from small communities' domestic wastewaters. As for phosphorus, different alternatives are possible but unlike $\mathrm{C}$ and $\mathrm{N}, \mathrm{P}$ can only be captured within the system and not removed from it or degraded into innocuous forms. In the system studied here (AZOE-NP ${ }^{\circledR}$, patent EP1857419A1; WO2012150296), dissolved phosphates are precipitated by injection of $\mathrm{FeCl}_{3}$ before the wastewater is percolated through the VFCW. The precipitates thus formed, mixed with the suspended solids already present in the wastewaters, thereby progressively accumulate as a sludge deposit layer at the surface of the VFCW (Kim et al., 2013).

Over the years of operation of VFCW, environmental or operational factors may induce stresses on $\mathrm{pH}$ and Eh. For example, along with domestic wastewaters, some plants may receive agricultural and/or industrial wastewaters such as winery effluents whose $\mathrm{pH}$ is 
relatively acidic (Masi et al., 2002; Shepherd et al., 2001) or brewery effluents whose pH is rather alkaline (Fillaudeau et al., 2006). Constructed wetlands may also be exposed to acidic rainfalls with pH reported to range from 4.4 to 5.7 in eastern France (Sanusi et al., 1996) and even as low as 2.9 in some parts of China (Du et al., 2014). Finally, temporary ill-functioning of the system resulting in the flooding of the filters may install reductive conditions within the sludge layer (Kim et al., 2015a).

These variations of $\mathrm{pH}$ and/or Eh are known to influence soil/plant/microorganism systems (Husson, 2012). For example, the dynamics of trace metals and organic matter (Blossfeld et al., 2010; Grybos et al., 2009) and P release (Castaldi et al., 2010; Christophoridis and Fytianos, 2006; Kjaergaard et al., 2012; Maine et al., 1992) can be affected. Very few studies are available however on the effect of such factors in constructed wetland (Braskerud et al., 2005), especially in vertical flow systems.

The present study was conducted to evaluate potential risks of P release during the operation of VFCW plants and gain better knowledge on the potential fate of phosphorus when the sludge should be dredged from the plant to avoid clogging of the filters after 10-15 years of operation. The scientific objectives were to (i) determine the influence of extreme conditions of $\mathrm{pH}$ and $\mathrm{Eh}$ on phosphorus release and (ii) characterize the effect of $\mathrm{P}$ leaching on its distribution and speciation within the sludge.

\section{Materials and Methods}

\subsection{Origin and composition of sludge samples}

Sludge samples were taken from the surface deposit layer of a full-scale AZOENP ${ }^{\circledR}$ plant located in Vercia (Jura, France) in operation for 8 years at the time sampling was done. It was designed to treat on a regular basis domestic wastewaters from the Vercia township, but also to receive winery effluents in autumn. Planted with Phragmites Australis, its maximum 
capacity corresponds to 1,100 people equivalent (PE) and previous studies reported its good performance (Kim et al., 2015b; Kim et al., 2014). The average depth of sludge layer accumulated on the first VFCW stage of this plant since its implantation was around $16 \mathrm{~cm}$, corresponding to a rate of accumulation of about $2 \mathrm{~cm}$ per year.

Primary sampling operations were conducted using an excavator (power shovel) to extract the entire depth of the deposit layer from various spots of the surface of the first filter. The samples were then treated manually to sort out rhizomes/roots and coarse fractions (gravels), and subsequently mixed by quartering before being transported to the laboratory. There, an aliquot fraction was spread in a few-cm thick layer, dried at $35^{\circ} \mathrm{C}$ and then manually crushed to a particle size below $1 \mathrm{~mm}$. The crushed dry materials were then stored at $4{ }^{\circ} \mathrm{C}$ until the beginning of experiments and analyses. According to the elemental analysis results of this sludge, total contents of $\mathrm{P}, \mathrm{Fe}, \mathrm{Ca}, \mathrm{Al}$ and $\mathrm{Mn}$ were found to be 2.57, 3.78, 4.54, 3.06 and $0.03 \%$ $\mathrm{w} / \mathrm{w}$ of dry matter, respectively. Additional information relative to the sludge from the same plant was reported previously by Kim et al. (Kim et al. 2013, Kim et al. 2015c).

\subsection{Experimental leaching protocol and leachates analyses}

The influence of $\mathrm{pH}$ and redox potential (Eh) on water-extraction of phosphorus from the sludge was investigated following a sequential leaching protocol. Ten grams of dry sludge were mixed in a $250 \mathrm{~mL}$ centrifuge tube (polypropylene copolymer, Nalgene ${ }^{\circledR}$ ) with $100 \mathrm{~mL}$ of leachant at each sequence. The following aqueous leachants were used.

- [Blank]: deionized water considered as reference conditions,

- [Acidic]: 0.01 M hydrochloric acid aqueous solution,

- [Alkaline]: 0.01 M sodium hydroxide aqueous solution,

- [Reduced]: 0.05 M sodium ascorbate aqueous solution (Chatain et al., 2005). 
Blanks and assays were all made in triplicates. The tubes were closed with a screw cap and placed on a rotary shaker at $9 \mathrm{rpm}$ at a temperature of $16 \pm 5^{\circ} \mathrm{C}$. After $24 \mathrm{~h}$, the tubes were rested for 5-10 minutes to allow settling of the suspensions before measurement of redox potential (Radiometer Analytical MC3051Pt combination metal electrode; Ag/AgCl reference, $\mathrm{HACH}), \mathrm{pH}$ (electrode Sentix ${ }^{\circledR}$; WTW) and temperature. The tubes were then centrifuged at $9000 \mathrm{rpm}$ (ca $13000 \mathrm{~g}$ ) for $20 \mathrm{~min}$. The supernatants were collected using disposable syringes, filtered through $0.45 \mu \mathrm{m}$ Sartorius Minisart filters and stored at $4^{\circ} \mathrm{C}$ before analyses. Each tube was filled again with fresh leachant to compensate the volume of supernatant extracted, and a new sequence was started. A total of 27 successive leaching sequences were performed. At the end of the experiment, sludge material was collected from each tube, freeze-dried, finely grinded and stored at $4{ }^{\circ} \mathrm{C}$ until being analyzed.

Each collected supernatant was analyzed for determination of dissolved molybdate reactive phosphorus concentration (MRP, mostly orthophosphates) according to the blue-molybdate method (Murphy and Riley, 1962) using a ShimadzuUV-2450 spectrophotometer. For the other analyses, supernatants of 3 replicates were mixed except if phosphorus concentrations revealed particular samples. Total concentrations of dissolved aluminum $(\mathrm{Al})$, calcium $(\mathrm{Ca})$, iron $(\mathrm{Fe})$ and manganese $(\mathrm{Mn})$ were determined by ICP OES (Ultima 2; Horiba Jobin Yvon SAS).

\subsection{Sequential phosphorus fractionation}

The fractionation protocol proposed by Golterman (1996) was followed.

Aliquots of the sludge sample were extracted at a solid to solution ratio of $1 \mathrm{~g} / 100 \mathrm{~mL}$ according to the following steps:

- 1 extraction of $2 \mathrm{~h}$ with deionized water,

- 4 extractions of $2 \mathrm{~h}$ with $0.05 \mathrm{M}$ Ca EDTA $+1 \%$ of Na dithionite; (pH around 7.5), 
- 2 extractions of 16h with 0.1 M Na EDTA ( $\mathrm{pH} 4.5$ ),

- 1 extraction of $30 \mathrm{~min}$ with $0.25 \mathrm{M} \mathrm{H}_{2} \mathrm{SO}_{4}$,

- 1 extraction of $30 \mathrm{~min}$ with $1 \mathrm{M} \mathrm{NaOH}$ at $90{ }^{\circ} \mathrm{C}$,

P extracted at each step was respectively considered to be associated to the following pools: water soluble phosphate $\left(\mathrm{H}_{2} \mathrm{O} \sim \mathrm{P}\right)$, iron bound phosphate $(\mathrm{Fe} \sim \mathrm{P})$, calcium bound phosphate (Ca P), acid soluble organic phosphate (ASOP, $\mathrm{P}_{\text {orgacid }}$ ) and alkali soluble organic phosphate ( $\mathrm{P}_{\text {orgalk})}$.

All extractions were carried out under continuous rotary shaking. Following extraction, each suspension was centrifuged at $4000 \mathrm{rpm}$ (ca $3400 \mathrm{~g}$ ) for $15 \mathrm{~min}$ then an aliquot fraction of the supernatant was analysed for dissolved MRP and total P determination. Total P concentration was measured by ICP-AES (Ultima 2; Horiba JobinYvon SAS). The difference between total $\mathrm{P}$ and MRP was referred to as molybdate unreactive phosphorus (MUP) which could include complex inorganic P forms, non-hydrolysed organic P and colloidal P (Cade-Menun and Liu, 2014; Haygarth and Sharpley, 2000).

\subsection{Solution ${ }^{31} \mathrm{P}$ nuclear magnetic resonance spectroscopy}

Solution ${ }^{31} \mathrm{P}$ NMR was used to seek information about the organic phosphorus species (Liu and Davis, 2014). Phosphorus was firstly extracted from the sludge material by mixing samples of freeze-dried sludge in a solution containing $0.25 \mathrm{M} \mathrm{NaOH}$ and $50 \mathrm{mM} \mathrm{Na} 2 \mathrm{EDTA}$. Mixing was conducted for $16 \mathrm{~h}$ at room temperature with a solid/liquid ratio of $1 \mathrm{~g} / 20 \mathrm{~mL}$. After centrifugation at $4000 \mathrm{rpm}$ (ca $3400 \mathrm{~g}$ ) for $15 \mathrm{~min}$, the supernatants were filtered $(0.45 \mu \mathrm{m}$; Sartorius Minisart). Each extract was then divided into two aliquots. The first one was used for determination of total P concentration and the other aliquot was freeze-dried and subsequently homogenized by manual grinding to a fine powder. 
For sample preparation, $100 \mathrm{mg}$ of each freeze-dried sample were dissolved into $900 \mu \mathrm{L}$ of $\mathrm{NaOH} / \mathrm{EDTA}$ solution and $100 \mu \mathrm{L}$ of $\mathrm{D}_{2} \mathrm{O} .{ }^{31} \mathrm{P}$ NMR spectra were recorded at $30^{\circ} \mathrm{C}$ using a BrukerAvance III HD $400 \mathrm{MHz}$ spectrometer equipped with a 5-mm QNP probe with z gradients and operated at $161.972 \mathrm{MHz}$. Experiments were recorded using $4.33 \mu$ s pulse $\left(60^{\circ}\right)$, a delay time of $2 \mathrm{~s}$, an acquisition time of $0.255 \mathrm{~s}$ and a number of scans of 4096 . Data were processed using the $5 \mathrm{~Hz}$ line broadening. Chemical shifts were indirectly reference to $\mathrm{H}_{3} \mathrm{PO}_{4}$ solution (at $\delta=0 \mathrm{ppm})$.

As paramagnetic ions could interfere with subsequent solution ${ }^{31} \mathrm{P}$ NMR spectroscopy, a treatment of $\mathrm{NaOH}-\mathrm{EDTA}$ extracts with a cation-exchange resin was performed on concerned sample (Turner, 2008). The Chelex-100 cation exchange resin (50-100 mesh; Sigma-Aldrich) which correspond to a styrene divinyl benzene copolymer with a high affinity for divalent cations (at $\mathrm{pH}>4$; especially transition metals such as iron and manganese), was chosen for this treatment. $\mathrm{NaOH}-\mathrm{EDTA}$ extracts containing high concentration of paramagnetic ions were shaken with Chelex resin (1:20 solid to solution ratio) for $1 \mathrm{~h}$ then proceeded as described above.

\section{Results and Discussion}

\subsection{Evolution of $\mathrm{pH}$ and Eh according to the nature of the leachant}

Figure 1 (a) shows the evolutions of $\mathrm{pH}$ and redox potential (Eh) along the successive leaching sequences. For deionized water series (DW, blank), almost no variations of pH (6.6 $\pm 0.1)$ and Eh $(416 \pm 36 \mathrm{mV} / \mathrm{SHE})$ were observed. With hydrochloric acid (A), the highest levels of Eh were recorded (518 $\pm 78 \mathrm{mV} / \mathrm{SHE})$. The $\mathrm{pH}$ decreased only slightly over the first 10 sequences (from 6.2 to 5.8), revealing the buffer capacity of the sludge, and then dropped to 3.6 in the rest of the experiment. With sodium hydroxide however (B), $\mathrm{pH}$ started to rise from the very beginning of the experiment ( $\mathrm{pH} 7.3)$ up to 11.7 at the end of the experiment 
revealing a smaller buffer capacity of the sludge against alkaline conditions. Under this condition, Eh values $(272 \pm 66 \mathrm{mV} / \mathrm{SHE})$ were significantly lower than observed in blank and under acidic conditions. With sodium ascorbate (reducing conditions), $\mathrm{pH}$ variations were small $(5.8 \pm 0.2)$ along the experiment as observed in the blank (deionized water). The recorded levels of Eh $(-176 \pm 113 \mathrm{mV} / \mathrm{SHE})$ were the lowest observed, revealing the installation of anoxic to anaerobic conditions.
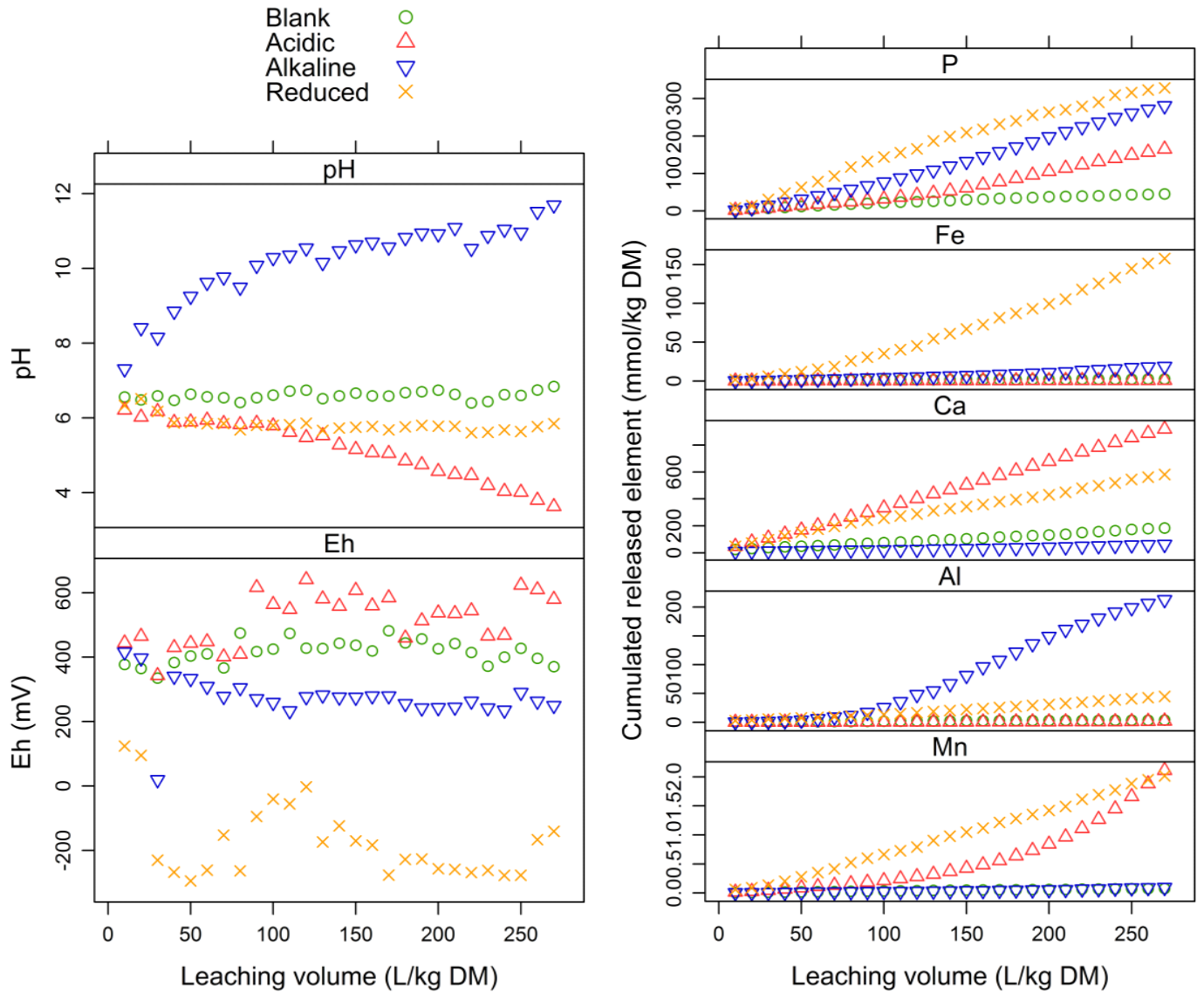

Figure 1. (a) Evolution of $\mathrm{pH}$ and redox potential [Eh] and (b) Cumulated release of selected elements along the successive leaching sequences in deionized water (blank) and under acidic (hydrochloric acid), alkaline (sodium hydroxide) and reduced (sodium ascorbate) conditions. 
The buffer capacity of soils is known to be controlled by organic matter and clay contents (Csoma, 2010; Murphy 2014). In the present case, the influence of organic matter can be considered predominant due to the very high organic matter of the sludge (59\%, Kim et al., 2013). Csoma (2010) investigated the acid and alkaline buffer capacities of 20 organic and 12 mineral materials. Regarding organic materials (peats, composts, organic manures) the author clearly observed that alkaline buffer capacity was smaller than acid buffer capacity which is in full agreement with our observations.

\subsection{Cumulated releases of monitored elements}

Figure 1 (b) and Table 1 show the cumulated amounts of released elements (P, Fe, Ca, Al and $\mathrm{Mn}$ ) expressed as mmol of each element per $\mathrm{kg}$ of dry matter (DM) of sludge samples. Over the whole experiment, a cumulated volume of $2700 \mathrm{~mL}$ of leachate was collected for each condition tested (i.e. $270 \mathrm{~L} \mathrm{~kg}^{1}$ of dry matter of sludge).

Table 1. Cumulated release of different elements over the 27 successive leaching sequences in deionized water (blank) and under acidic (hydrochloric acid), alkaline (sodium hydroxide) and reduced (sodium ascorbate) conditions.

\begin{tabular}{lllll}
\hline & Blank & Acidic & Alkaline & Reduced \\
\hline Element & mmol.kg $^{1}(\%)$ & $\mathrm{mmol.kg}^{1}(\%)$ & mmol.kg $(\%)$ & mmol.kg $(\%)$ \\
\hline P & $45(5.5)$ & $165(19.9)$ & $281(33.7)$ & $329(39.5)$ \\
\hline Fe & $2.5(0.4)$ & $0.8(0.1)$ & $19(2.8)$ & $158(23.3)$ \\
\hline Ca & $184(16.2)$ & $919(81.1)$ & $61(5.4)$ & $582(51.4)$ \\
\hline Al & $3.5(0.3)$ & $2.0(0.2)$ & $213(18.8)$ & $45(4.0)$ \\
\hline Mn & $0.08(1.5)$ & $2.1(41.8)$ & $0.09(1.8)$ & $2.0(40.0)$ \\
\hline
\end{tabular}

Phosphorus leaching from sludge was found to be low in the blank, not exceeding over the whole experiment $5.5 \%$ of the total $\mathrm{P}$ content, confirming that $\mathrm{P}$ species were poorly extractible in water considering the very high cumulated extraction volume. This result was in 
agreement with the low content of water-extractible $\mathrm{P}(1.5 \%$ of total $\mathrm{P})$ determined by sequential extraction by Kim et al. (2015). Over the whole experiment, the extent of P release was higher under alkaline $(34 \%$ of total $\mathrm{P}$ content) than acidic conditions $(20 \%$ of total $\mathrm{P}$ content) which may be related to the lower alkaline buffer capacity of the sludge. The strongest leaching was observed under reduced conditions (39.5\% of total $\mathrm{P}$ content), indicating a specific influence of Eh, stronger than that of $\mathrm{pH}$ within the ranges studied here. The extraction of iron was also very poor in water $(0.4 \%$ of total Fe content) and almost nil under acidic condition in the range tested. A slight release was observed under alkaline conditions $(2.8 \%$ of total $\mathrm{Fe}$ content) but much less than observed under reduced condition ( $23 \%$ of total $\mathrm{Fe}$ content), indicating that the Eh was the governing parameter for iron release. The reduction of oxyhydroxides species was considered to be the most probable process.

Calcium behavior exhibited quite a different pattern than iron's. The leaching of calcium was found to be very pronounced under acidic conditions ( $81 \%$ of total Ca content) whereas only $5.4 \%$ of $\mathrm{Ca}$ was extracted under alkaline conditions and $16 \%$ in the blank. Under reduced conditions, a relatively high release of $\mathrm{Ca}$ was observed ( $51 \%$ of total $\mathrm{Ca}$ content). Since $\mathrm{Ca}$ species within wetlands are not known to be sensitive to redox conditions (Golterman, 1998), this observation may rather be attributed to the acidity of the reducing reagent (sodium ascorbate), and/or the ion exchange between sodium and calcium, than the Eh itself.

Al was not significantly released in the tested experimental conditions except in alkaline extractions (19\% of total Al content), which may be attributed to its amphoteric properties. On the other hand, Mn release was fairly high under reduced and acidic conditions (40 and 42\% of total Mn content, respectively), as commonly observed in the literature (Chen et al., 2015). 


\subsection{Evolution of organic P forms}

Organic forms represented a small but non negligible fraction $(5 \%)$ of phosphorus in the sludge (Kim et al., 2015c). Due to the high content in organic matter in the sludge, the contribution of this pool to the leaching of phosphorus was investigated. Solution ${ }^{31} \mathrm{P}$ NMR spectra of $\mathrm{NaOH}-\mathrm{EDTA}$ extracts are shown in figure 2 and relative percentages of organic $\mathrm{P}$ species in the solids given in Table 2. Literature data were used for peak assignments as follows: peaks between 5.3 and 6.6 ppm were assigned to orthophosphate (Cade-Menun et al., 2005; Newman and Tate, 1980), between 3 and 5 ppm to orthophosphate monoesters (Newman and Tate, 1980), between -1 and 2.5 ppm to orthophosphate diesters (Makarov et al., 2002) and between -4.5 and -3.5 ppm to pyrophosphate (Turner et al., 2003). Polyphosphates, usually found around -19 ppm (Turner et al., 2003), were not observed in any spectrum.

Table 2. Relative percentages of organic P species, determined by solution ${ }^{31} \mathrm{P}$ NMR spectroscopy for initial sludge (initial), sludge leached by deionized water (blank), hydrochloric acid (acidic), sodium hydroxide (alkaline) and sodium ascorbate (reduced). Results are expressed as mass \% of extracted organic P.

\begin{tabular}{|c|c|c|c|c|}
\hline Sample & $\begin{array}{c}\text { Porthomono } \\
(\%)\end{array}$ & $\begin{array}{c}\text { Porthodi } \\
\text { (\%) }\end{array}$ & $\begin{array}{c}\text { PPhosphonate } \\
(\%)\end{array}$ & $\begin{array}{c}\text { Ratio } \\
(\text { Pdiester } / \\
\text { P monoester } \text { ) }\end{array}$ \\
\hline Initial & 75.7 & 10.8 & 13.5 & 0.14 \\
\hline Blank & 75.0 & 10.0 & 15.0 & 0.13 \\
\hline Acidic & 66.2 & 15.6 & 18.2 & 0.24 \\
\hline Alkaline & 97.8 & $-\dagger$ & 2.2 & - \\
\hline Reduced & 70.7 & 18.9 & 10.4 & 0.27 \\
\hline
\end{tabular}




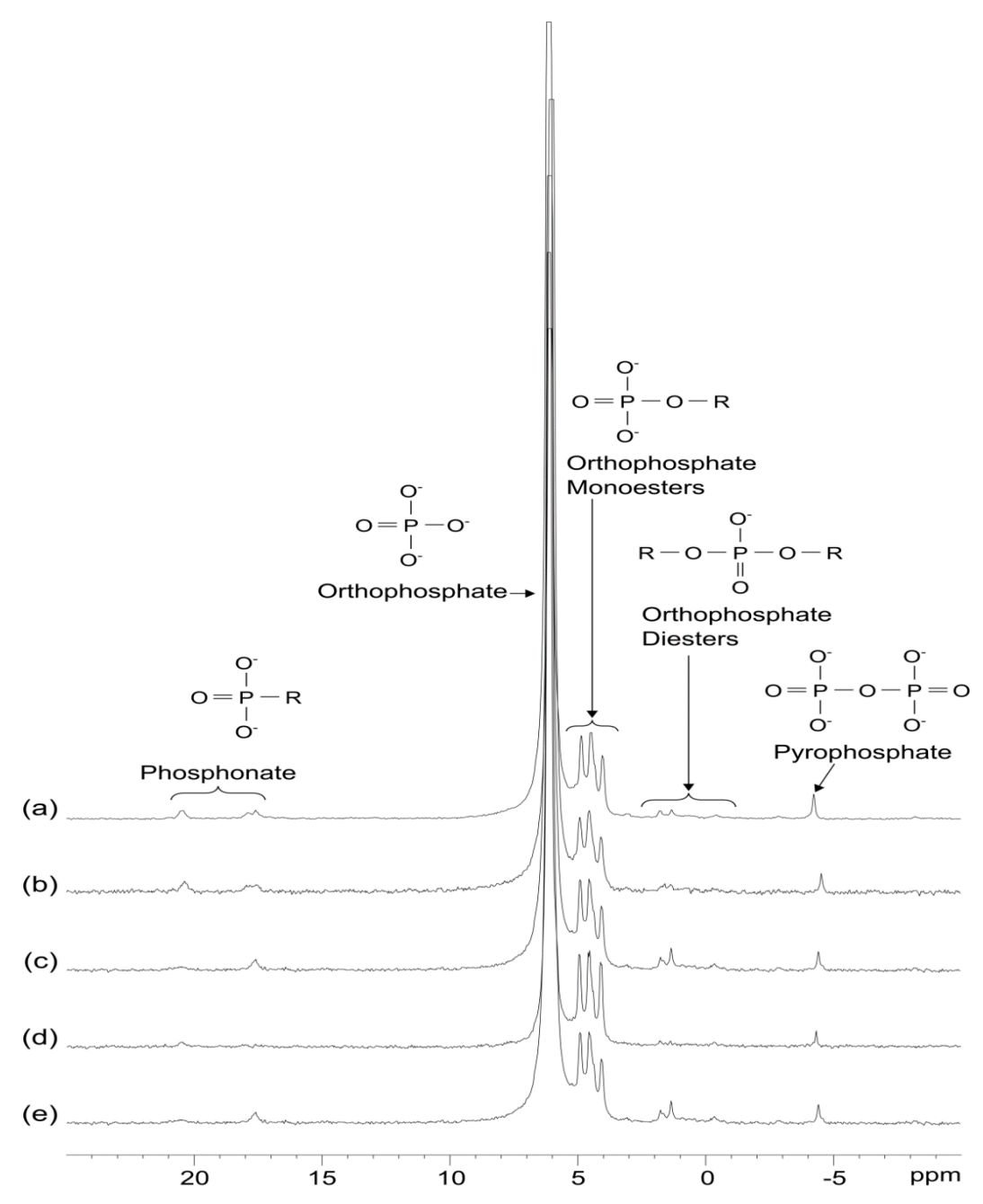

Figure 2. $\quad{ }^{31} \mathrm{P}$ NMR spectra of $\mathrm{NaOH}-\mathrm{EDTA}$ extracts of sludge samples (a) initial sludge before leaching, after leaching under (b) blank (deionized water), (c) acidic (hydrochloric acid), (d) alkaline (sodium hydroxide) and (e) reduced (sodium ascorbate) conditions.

Most of organic P extracted from the sludge solids before leaching consisted in P-monosters (75.7\% of total organic $\mathrm{P}$ extracted), followed by phosphonate $(13.5 \%$ of total organic $\mathrm{P}$ extracted) and diesters (10.8\% of total organic P extracted).

Leaching under acidic or reduced conditions induced a strong increase of the diesters to monoesters ratio in the sludge (from 0.14 to 0.24 or 0.27 , respectively), indicating that monoesters were more easily leached than diesters under such conditions. On the contrary, diesters were not observed anymore in the residual solids after alkaline leaching, which were 
attributed to their alkaline hydrolysis (Leinweber et al., 1997; McDowell and Stewart, 2006). Probably for the same reasons, the proportion of phosphonates was slightly decreased by alkaline leaching.

\subsection{Effect of leaching conditions on $\mathrm{P}$ distribution within the solids}

In the leaching experiments, phosphorus input was entirely present within the sludge solids. It was therefore initially distributed exclusively within the different pools identified by $\mathrm{P}$ fractionation of the sludge shown in Figure 3. Fe P species were initially predominant $(60.9 \%$ of total $\mathrm{P}$ content) and $\mathrm{Ca}, \mathrm{Al} \sim \mathrm{P}$ fraction was analyzed in second highest proportion (28\% of total $\mathrm{P})$. Alkali soluble organic $\mathrm{P}$ fraction $\left(\mathrm{P}_{\text {orgalk }} ; 4.0 \%\right.$ of total $\left.\mathrm{P}\right)$, water-extractible fraction $\left(\mathrm{H}_{2} \mathrm{O} \sim \mathrm{P} ; 1.5 \%\right.$ of total $\left.\mathrm{P}\right)$, and acid soluble organic fraction $\left(\mathrm{P}_{\text {orgacid }} ; 0.8 \%\right.$ of total $\left.\mathrm{P}\right)$ were analyzed in smaller proportions. Detailed information on P speciation in the considered sludge material was published in a recent article by the authors (Kim et al., 2015c).

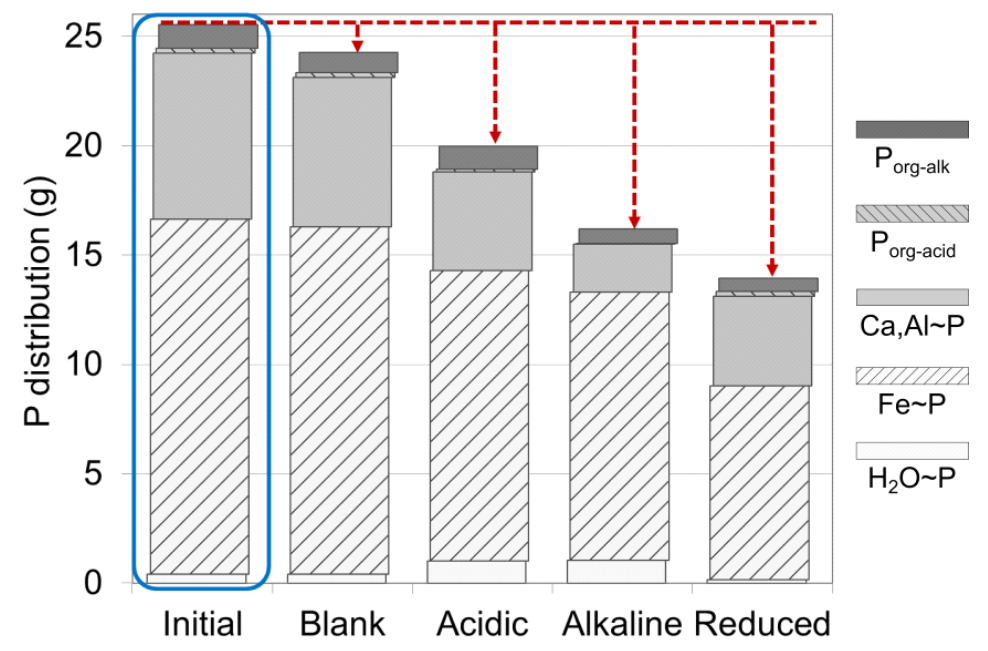

Figure 3. Distribution of P (in g) before leaching (initial sludge solids) and after leaching (residual solids + solution) in deionized water (blank), hydrochloric acid (acidic), sodium hydroxide (alkaline) and sodium ascorbate (reduced). The masses of $\mathrm{P}$ in the pools of the initial and residual solids were obtained by $\mathrm{P}$ fractionation protocol. Arrows indicate the cumulated masses of $\mathrm{P}$ leached into the solutions under the different conditions. 
Figure 3 also shows the cumulated masses of phosphorus leached under the different conditions tested (arrows) and the distribution of phosphorus within the pools of the residual solids collected at the completion of the leaching sequences.

Phosphorus leaching in the blanks was very small as discussed above. Consequently, phosphorus distribution in the residual solids was very similar to that observed in the initial sludge solids.

The easily soluble $\mathrm{P}$ forms (fraction $\mathrm{H}_{2} \mathrm{O}-\mathrm{P}$ ) were found to increase under acidic and alkaline conditions. This apparently surprising observation was attributed to the physical changes occurring within the sludge matrix due to physicochemical stresses from leaching sequences which probably eroded and weakened the sludge structure.

The masses of $\mathrm{P}$ in the Fe-P pool were found to decrease in all assays. The extent of the decreases was correlated with the cumulated masses of phosphorus leached. Hence, under reducing conditions where phosphorus leaching was the highest (close to $40 \%$, Table 2), the Fe-P fraction was found to decrease by close to $45 \%$ as confirmed by the regular leaching of iron shown in Figure 1. This result showed that the reductive dissolution of ferric species and the concomitant release of adsorbed phosphates was a major process of phosphorus leaching. However, even though the Fe-P fraction was responsible in mass terms for most of phosphorus leached under reduced conditions, the proportion of $\mathrm{P}$ leached from this pool (close to $45 \%$ ) was similar to the respective contribution of $\mathrm{Ca}, \mathrm{Al} \sim \mathrm{P}$ pool $(46 \%)$ or even $\mathrm{P}_{\text {orgalk }}(46 \%)$. Leaching under reduced conditions therefore did not exclusively affect Fe-P fraction, partly due to the combined effects of the acidity of the reducing agent used.

As a matter of fact, under acidic conditions, the mass of $\mathrm{P}$ in $\mathrm{Ca}, \mathrm{Al} \sim \mathrm{P}$ fraction decreased by $41 \%$, as confirmed by the regular leaching of calcium observed in Figure 3. A slight decrease of the mass of $\mathrm{P}$ in $\mathrm{Fe} \sim \mathrm{P}$ fraction was also observed in Figure $3(18 \%)$, suggesting that Febound phosphorus within the initial sludge was at least partly in the form of phosphate 
adsorbed onto iron hydroxides which were susceptible to dissolve under acidic conditions. However, the final $\mathrm{pH}$ of the acidic assays (below 4) was favorable for the re-precipitation of phosphates and ferric ions into iron phosphate $\left(\mathrm{FePO}_{4}\right)$, which would therefore be analyzed in the Fe P fraction within the residual solids. This phenomenon may explain why the observed decrease of the mass of phosphorus in $\mathrm{Fe} \sim \mathrm{P}$ fraction was small and the leaching of iron observed under acidic conditions (Figure 1) was low itself.

Finally, under alkaline conditions, the alkaline soluble organic $\mathrm{P}$ fraction decreased as expected. The mass of $\mathrm{P}$ also decreased within $\mathrm{Fe} \sim \mathrm{P}$ fraction $(24 \%)$ but a much stronger decrease of $\mathrm{P}$ was observed in $\mathrm{Ca}, \mathrm{Al} \sim \mathrm{P}$ fraction (close to $72 \%$ ). A direct effect of alkaline conditions on the dissolution of P-bearing Fe or $\mathrm{Ca}$ species would be unlikely. Only very slight leaching of calcium and iron where indeed observed under alkaline conditions (Figure 1). The re-precipitation of these elements could not occur since the final $\mathrm{pH}(11.5)$ and their ranges of concentrations in the solutions were below the solubility product of $\mathrm{Ca}$ and Fe hydroxides.

Although calcium phosphate would be expected to precipitate at alkaline $\mathrm{pH}$, Alvarez et al. (2004) highlighted that the presence of soil humic substances at a concentration around $2 \mathrm{~g} / \mathrm{L}$ inhibited calcium phosphate precipitation. The humic substances content of the sludge studied here was analyzed at around 4\% (Kania et al., 2015), thereby providing conditions that may induce this inhibition. Moreover, the observed leaching of Al during our assays (Figure 1) suggested a possible contribution of Al-P species dissolution. The strong decrease of Ca,Al P fractions in the residual solids after leaching under alkaline conditions may therefore be attributed to these phenomena. 


\subsection{Factors of influence of $\mathrm{P}$ release or extraction}

In the objective to estimate the possible correlations between the variables followed, experimental data were treated through PCA. Results showed that only the first two principal components had statistically significant Eigen values (>1). These 2 axes accounted for $77.7 \%$ of the total variance. Figure 4 shows the position of the selected variables on the correlations circle (a) and a plot of individual data points (b) on the plane represented by the first two principal component axes.

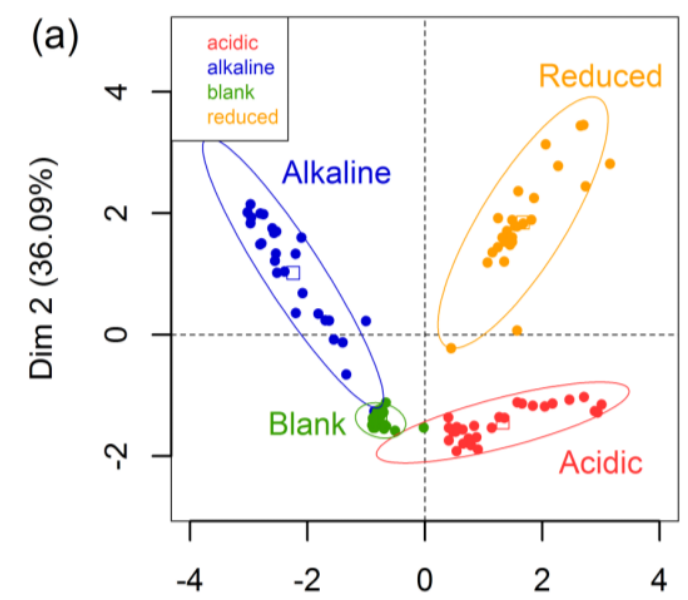

$\operatorname{Dim} 1(41.63 \%)$

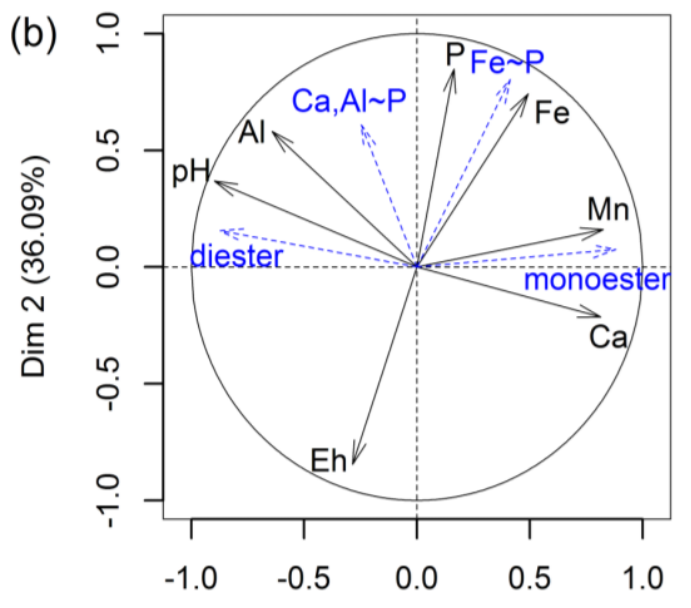

$\operatorname{Dim} 1(41.63 \%)$

Figure 4. PCA plot of individual data (a) and variables plot on the correlation circle (b).

The plot of individual data points (Figure 4, a) showed that the different leaching conditions (blank, acidic, alkaline and reduced) resulted clearly in the identification of four statistically distinct groups. In a logical manner, the "acidic" and "alkaline" data groups were mainly identified by their correlation with $\mathrm{pH}$ whereas the "reduced" data group was mainly governed by redox conditions.

The first component, accounting for $41.6 \%$ of the total variance, was correlated primarily with $\mathrm{pH}, \mathrm{Ca}, \mathrm{Al}$ and $\mathrm{Mn}$, confirming $\mathrm{pH}$ dependent releases of those elements ( $\mathrm{Al}$ release under 
alkaline $\mathrm{pH}$; $\mathrm{Ca}$ and $\mathrm{Mn}$ releases under acidic $\mathrm{pH}$ ). The second component, accounting for $36.1 \%$ of the variance, was correlated with $\mathrm{Eh}, \mathrm{Fe}$ and $\mathrm{P}$, confirming the strong Eh dependence of Fe release. The negative correlation between Eh and P release suggested that the reduction of P-bearing ferric species was a major mechanism of $\mathrm{P}$ release from the studied sludge.

The addition of four supplementary variables (Fe P; Ca,Al P; monoester; diester; Figure 4, b) into the correlation circle allowed to investigate the relationship between the dissolution of $\mathrm{P}$ bearing solid phases and releases of their constituents into the aqueous solution. Positions of those variables on the correlation circle indicated that the dissolution of solid phases may not be correctly appreciated by monitoring solely the transfer of their constitutive elements into the solution. Both solution and solid materials had to be analyzed to allow a relevant description of leaching phenomena.

\section{Conclusions}

The reversibility of $\mathrm{P}$ capture by $\mathrm{FeCl}_{3}$ injection within the sludge deposit layer of an operating VFCW was assessed by studying adverse effects of $\mathrm{pH}$ and Eh stresses on a representative sludge sample taken from a VFCW plant treating mostly domestic wastewater according to the AZOE-NP ${ }^{\circledR}$ process. Series of 27 sequential batch leaching tests were conducted at a L/S ratio of 10 to evaluate the maximal extraction of $\mathrm{P}$ and other elements by submitting the sludge to a volume of water equivalent to 10 years of rain in the field (Vercia, France), and to extreme condition of $\mathrm{pH}$ and Eh depending on the leaching solutions used.

Chemical P fractionation on the sludge before and after leaching tests showed that inorganic phases were the major pool of $\mathrm{P}$ release under the tested conditions. Solution ${ }^{31} \mathrm{P}$ NMR 
confirmed that the organic $\mathrm{P}$ forms were not significantly affected, except under alkaline conditions. PCA results statistically validated experimental observations and highlighted the complementarity of solutions' and solids' analyses to effectively assess the leaching processes. Results from this study allowed to conclude that the risk of accidental release of phosphorus into the environment would be extremely low during the operation of the plant. They also suggested that phosphorus would be leached at a low but regular rate in case of land application of the dredged sludge, thereby potentially satisfying the needs of the crops without the risk of surface- or ground-waters contamination which might result from excessive phosphorus release.

\section{Acknowledgements}

The authors are grateful to SCIRPE and CIFRE (Conventions Industrielles de Formation par la REcherche) for funding this research. They also would like to thank Ruben Vera from Henri Longchambon diffractometry centre, Nathalie Dumont and David Lebouil of LGCIE for chemical analysis (ICP-AES and ion chromatography) and the SARM (Service of Analyses of Rocks and Minerals) for chemical elemental analyses. 


\section{References}

Alvarez, R., Evans, L.A., Milham, P.J. and Wilson, M.A. (2004) Effects of humic material on the precipitation of calcium phosphate. Geoderma 118(3-4), 245-260.

Blossfeld, S., Perriguey, J., Sterckeman, T., Morel, J.-L. and Lösch, R. (2010) Rhizosphere $\mathrm{pH}$ dynamics in trace-metal-contaminated soils, monitored with planar $\mathrm{pH}$ optodes. Plant and Soil 330(1-2), 173-184.

Braskerud, B.C., Hartnik, T. and Lovstad, O. (2005) The effect of the redox-potential on the retention of phosphorus in a small constructed wetland. Water Science and Technology: A Journal of the International Association on Water Pollution Research 51(3-4), 127-134.

Brod, E., Øgaard, A.F., Hansen, E., Wragg, D., Haraldsen, T.K. and Krogstad, T. (2015a) Waste products as alternative phosphorus fertilisers part I: inorganic $\mathrm{P}$ species affect fertilisation effects depending on soil pH. Nutrient Cycling in Agroecosystems 103(2), 167-185.

Brod, E., Øgaard, A.F., Haraldsen, T.K. and Krogstad, T. (2015b) Waste products as alternative phosphorus fertilisers part II: predicting $\mathrm{P}$ fertilisation effects by chemical extraction. Nutrient Cycling in Agroecosystems 103(2), 187-199.

Cade-Menun, B. and Liu, C.W. (2014) Solution Phosphorus-31 Nuclear Magnetic Resonance Spectroscopy of Soils from 2005 to 2013: A Review of Sample Preparation and Experimental Parameters. Soil Science Society of America Journal 78(1), 19-37.

Cade-Menun, B.J. (2005) Characterizing phosphorus in environmental and agricultural samples by 31P nuclear magnetic resonance spectroscopy. Talanta 66(2), 359-371.

Castaldi, P., Silvetti, M., Garau, G. and Deiana, S. (2010) Influence of the pH on the accumulation of phosphate by red mud (a bauxite ore processing waste). Journal of Hazardous Materials 182(1-3), 266-272.

Chatain, V., Sanchez, F., Bayard, R., Moszkowicz, P. and Gourdon, R. (2005) Effect of experimentally induced reducing conditions on the mobility of arsenic from a mining soil. Journal of Hazardous Materials 122(1-2), 119-128.

Chen, L., Zheng, X., Wang, T. and Zhang, J. (2015) Influences of key factors on manganese release from soil of a reservoir shore. Environmental Science and Pollution Research 22(15), 11801-11812.

Christophoridis, C. and Fytianos, K. (2006) Conditions affecting the release of phosphorus from surface lake sediments. Journal of Environmental Quality 35(4), 1181-1192.

Cordell, D., Drangert, J.-O. and White, S. (2009) The story of phosphorus: Global food security and food for thought. Global Environmental Change 19(2), 292-305.

Csoma, Z. (2010) The factors influencing the buffering capacity of soils and their importance in horticultural cultivation, Corvinus university of Budapest.

Du, Y.-J., Wei, M.-L., Reddy, K.R., Liu, Z.-P. and Jin, F. (2014) Effect of acid rain pH on leaching behavior of cement stabilized lead-contaminated soil. Journal of Hazardous Materials 271, 131-140.

Fillaudeau, L., Blanpain-Avet, P. and Daufin, G. (2006) Water, wastewater and waste management in brewing industries. Journal of Cleaner Production 14(5), 463-471.

García-Albacete, M., Martín, A. and Cartagena, M.C. (2012) Fractionation of phosphorus biowastes: Characterisation and environmental risk. Waste Management 32(6), 10611068.

Golterman, H. (1996) Fractionation of sediment phosphate with chelating compounds: a simplification, and comparison with other methods. Hydrobiologia 335(1), 87-95.

Golterman, H.L. (1998) The distribution of phosphate over iron-bound and calcium-bound phosphate in stratified sediments. Hydrobiologia 364, 75-81. 
Grybos, M., Davranche, M., Gruau, G., Petitjean, P. and Pédrot, M. (2009) Increasing pH drives organic matter solubilization from wetland soils under reducing conditions. Geoderma 154(1-2), 13-19.

Haygarth, P.M. and Sharpley, A.N. (2000) Terminology for Phosphorus Transfer. Journal of Environmental Quality 29(1), 10-15.

Husson, O. (2012) Redox potential (Eh) and $\mathrm{pH}$ as drivers of soil/plant/microorganism systems: a transdisciplinary overview pointing to integrative opportunities for agronomy. Plant and Soil 362(1-2), 389-417.

Kahiluoto, H., Kuisma, M., Ketoja, E., Salo, T. and Heikkinen, J. (2015) Phosphorus in Manure and Sewage Sludge More Recyclable than in Soluble Inorganic Fertilizer. Environmental Science \& Technology 49(4), 2115-2122.

Kania, M., Gautier, M., Michel, P. and Gourdon, R. (2015) Effects of influent pre-treatments by biological trickling filter and $\mathrm{FeCl} 3$ injection on the characteristics of sludge surface deposit from VFCW municipal units treating domestic wastewaters. Gabriela, D. and Vincent, G. (eds), pp. 270-271, Proceeding of the 6th International Symposium on Wetland Pollutant Dynamics and Control, York, United Kingdom.

Kim, B., Gautier, M., Michel, P. and Gourdon, R. (2013) Physical-chemical characterization of sludge and granular materials from a vertical flow constructed wetland for municipal wastewater treatment. Water Science and Technology 68(10), 2257-2263.

Kim, B., Gautier, M., Molle, P., Michel, P. and Gourdon, R. (2015a) Influence of the water saturation level on phosphorus retention and treatment performances of vertical flow constructed wetland combined with trickling filter and $\mathrm{FeCl} 3$ injection. Ecological Engineering 80, 53-61.

Kim, B., Gautier, M., Olvera Palma, G., Molle, P., Michel, P. and Gourdon, R. (2015b) Pilotscale study of vertical flow constructed wetland combined with trickling filter and ferric chloride coagulation: influence of irregular operational conditions. Water Science and Technology 71(7), 1088-1096.

Kim, B., Gautier, M., Prost-Boucle, S., Molle, P., Michel, P. and Gourdon, R. (2014) Performance evaluation of partially saturated vertical-flow constructed wetland with trickling filter and chemical precipitation for domestic and winery wastewaters treatment. Ecological Engineering 71, 41-47.

Kim, B., Gautier, M., Rivard, C., Sanglar, C., Michel, P. and Gourdon, R. (2015c) Effect of Aging on Phosphorus Speciation in Surface Deposit of a Vertical Flow Constructed Wetland. Environmental Science \& Technology 49(8), 4903-4910.

Kjaergaard, C., Heiberg, L., Jensen, H.S. and Hansen, H.C.B. (2012) Phosphorus mobilization in rewetted peat and sand at variable flow rate and redox regimes. Geoderma 173-174, 311-321.

Leinweber, P., Haumaier, L. and Zech, W. (1997) Sequential extractions and 31P-NMR spectroscopy of phosphorus forms in animal manures, whole soils and particle-size separates from a densely populated livestock area in northwest Germany. Biology and Fertility of Soils 25(1), 89-94.

Liu, J. and Davis, A.P. (2014) Phosphorus Speciation and Treatment Using Enhanced Phosphorus Removal Bioretention. Environmental Science \& Technology 48(1), 607 614.

Maine, M.A., Hammerly, J.A., Leguizamon, M.S. and Pizarro, M.J. (1992) Influence of the $\mathrm{pH}$ and redox potential on phosphate activity in the Parana Medio system. Hydrobiologia 228(1), 83-90.

Makarov, M., Haumaier, L. and Zech, W. (2002) The nature and origins of diester phosphates in soils: a 31P-NMR study. Biology and Fertility of Soils 35(2), 136-146. 
Masi, F., Conte, G., Martinuzzi, N. and Pucci, B. (2002) Winery high organic content wastewater treated by constructed wetlands in Mediterranean climate, pp. 274-282, Arusha (TZ).

McDowell, R.W. and Stewart, I. (2006) The phosphorus composition of contrasting soils in pastoral, native and forest management in Otago, New Zealand: Sequential extraction and 31P NMR. Geoderma 130(1-2), 176-189.

Murphy, J. and Riley, J.P. (1962) A modified single solution method for the determination of phosphate in natural waters. Analytica Chimica Acta 27(0), 31-36.

Murphy, B. (2014) Soil organic matter and soil function - Review of the literature and underlying data, p. 155, Department of the Environment, Canberra, Australia.

Newman, R.H. and Tate, K.R. (1980) Soil phosphorus characterisation by 31p nuclear magnetic resonance. Communications in Soil Science and Plant Analysis 11(9), 835842.

Peccia, J. and Westerhoff, P. (2015) We Should Expect More out of Our Sewage Sludge. Environmental Science \& Technology 49(14), 8271-8276.

Reijnders, L. (2014) Phosphorus resources, their depletion and conservation, a review. Resources, Conservation and Recycling 93, 32-49.

Sanusi, A., Wortham, H., Millet, M. and Mirabel, P. (1996) Chemical composition of rainwater in Eastern France. Atmospheric Environment 30(1), 59-71.

Sharpley, A.N., Bergström, L., Aronsson, H., Bechmann, M., Bolster, C.H., Börling, K., Djodjic, F., Jarvie, H.P., Schoumans, O.F., Stamm, C., Tonderski, K.S., Ulén, B., Uusitalo, R. and Withers, P.J.A. (2015) Future agriculture with minimized phosphorus losses to waters: Research needs and direction. AMBIO 44(2), 163-179.

Shepherd, H.L., Grismer, M.E. and Tchobanoglous, G. (2001) Treatment of High-Strength Winery Wastewater Using a Subsurface-Flow Constructed Wetland. Water Environment Research 73(4), 394-403.

Turner, B.L. (2008) Soil organic phosphorus in tropical forests: an assessment of the NaOHEDTA extraction procedure for quantitative analysis by solution 31P NMR spectroscopy. European Journal of Soil Science 59(3), 453-466.

Turner, B.L., Driessen, J.P., Haygarth, P.M. and McKelvie, I.D. (2003) Potential contribution of lysed bacterial cells to phosphorus solubilisation in two rewetted Australian pasture soils. Soil Biology and Biochemistry 35(1), 187-189.

Vymazal, J. and Kröpfelová, L. (2009) Removal of organics in constructed wetlands with horizontal sub-surface flow: A review of the field experience. Science of The Total Environment 407(13), 3911-3922.

Weigand, H., Bertau, M., Hübner, W., Bohndick, F. and Bruckert, A. (2013) RecoPhos: Fullscale fertilizer production from sewage sludge ash. Waste Management 33(3), 540-544.

Wilfert, P., Kumar, P.S., Korving, L., Witkamp, G.-J. and van Loosdrecht, M.C.M. (2015) The Relevance of Phosphorus and Iron Chemistry to the Recovery of Phosphorus from Wastewater: A Review. Environmental Science \& Technology 49(16), 9400-9414. 